\title{
Irrigation impact on harvest efficiency in grazed Old World bluestem
}

\author{
W.R. TEAGUE AND S.L. DOWHOWER
}

Authors are Associate Professor and senior Research Associate, Texas Agricultural Experiment Station, P.O. Box 1658, Vernon, Tex. 76385.

\begin{abstract}
In 1992 and 1993, pastures of WW-Spar Old World bluestem (Bothriochloa ischaemum L.) were maintained at 2 levels of soil water, rainfall and rainfall plus $25 \mathrm{~mm} /$ week of supplementary irrigation. At both moisture levels the grass was maintained at 2 levels of standing crop, averaging 1,548 and $2,154 \mathrm{~kg} \mathrm{ha}^{-1}$, using continuous variable stocking. Measurements were made to determine how different levels of soil moisture interacted with grazing intensity to change leaf area index, leaf-stem and live-dead ratios, tiller density, and the proportion of gross leaf production that was grazed (harvest efficiency). The proportions of live to dead, and leaf and stem biomass, remained constant under the different levels of soil water content. Soil water content alone had no effect on leaf area index, tiller density and the proportion of live or dead, leaf and stem. Winter tiller survival was significantly higher in the pastures with higher soil water content. Increasing soil water content and increasing grazing intensity interacted to reduce the proportion of dead leaf, increase production of new tillers, and increase the proportion of leaf grazed by decreasing leaf that died and was not grazed. This study indicates that if continuously grazed Old World bluestem was maintained at a standing crop of $1,500 \mathrm{~kg} \mathrm{ha}^{-1}$, harvest efficiency would be higher in wet years or under irrigation than if standing crop was higher.
\end{abstract}

Key Words: Bothriochloa ischaemum, continuous variable stocking, herbage allowance

Old World bluestem (Bothriochloa ischaemum L.) pastures are widely used to enhance production and profitability of rangebased beef systems in the southern plains of North America (Sims and Dewald 1982, Coyne and Bradford 1985). This species is easy to establish, drought hardy, resistant to defoliation and produces moderate quality forage in spring and summer, but forage quality in late summer through winter is very low (Eck and Sims 1984, Dabo et al. 1987). Diet quality, intake, and animal performance of animals grazing Old World bluestem are particu-

We gratefully acknowledge the facilities and livestock made available to us by Dr. Marvin Sharp and the financial support of the E. Paul and Helen Buck Waggoner Foundation, Inc. We thank Jeff Estes, Paula Martinez, Chad Sosolik and Jan Worrall for technical support. David Briske, Jerry Cox, Mort Kothmann, Don Robinson and Darek Malinowski kindly reviewed this manuscript.

Manuscript accepted 22 Aug. 2001.

\section{Resumen}

En 1992 y 1993 poteros de WW-Spar "Old World bluestem" (Bothriochloa ischaemum L.) se mantuvieron en dos niveles de humedad del suelo, humedad proveniente de la lluvia y humedad producto de la lluvia mas $25 \mathrm{~mm} / \mathrm{semana}$ de irrigación suplementaria. En ambos niveles de humedad el zacate se mantuvo en 2 niveles de cosecha en pie, 1,548 y $2,154 \mathrm{~kg} \mathrm{ha}^{-1}$ en promedio, para lo cual se utilizo una carga animal continua variable. Las mediciones se hicieron para determinar como los diferentes niveles de humedad del suelo interactuaron con la intensidad de apacentamiento para cambiar el indice de área foliar, las relaciones tallo-hoja y biomasa viva-muerta, la densidad de hijuelos y la proporción de producción total de hojas que fue apacentada (eficiencia de cosecha). Las proporciones de biomasa viva-muerta y tallo-hoja permanecieron constantes bajo los diferentes niveles de humedad del suelo. El contenido de humedad del suelo solo no tuvo efecto en el indice de área foliar, la densidad de hijuelos y las proporciones de biomasa viva-muerta y tallo-hoja. La sobrevivencia de los hijuelos en invierno fue significativamente mayor en los potreros con alto contenido de agua en el suelo. El aumento del contenido de agua en el suelo y la intensidad de apacentamiento interactuaron para reducir la proporción de hojas muertas, incrementar la producción de nuevos hijuelos e incrementar la proporción de hojas apacentadas al disminuir las hojas muertas y no fueron apacentadas. Este estudio indica que si las praderas de "Old World bluestem" apacentadas continuamente se mantuvieran con una biomasa en pie de $1,500 \mathrm{~kg} \mathrm{ha}^{-1}$, la eficiencia de cosecha sería mayor en los años húmedos o bajo irrigación que si la cosecha en pie fuera mayor.

larly sensitive to the proportion and density of green leaf mass and the leaf to stem ratio (Forbes and Coleman 1986, Teague et al. 1996).

Under continuous grazing, the rapid turnover of leaves on tillers has meant that maximizing yield per hectare (amount harvested by grazing) does not depend on maximizing photosynthesis and the gross rate of tissue production, since such management also results in high rates of leaf senescence. Maximum yield per hectare is achieved when the pasture is maintained at a relatively low leaf area index (LAI), which is usually at lower gross tissue production (Grant et al. 1983, Parsons et al. 1983a, 1983b). Lower LAI increases harvest efficiency, since a greater percentage of leaf is consumed before it dies and different pasture structure provides the grazing animal greater leaf densities and a diet 
proportionally greater in leaf and nutrients (Grant et al. 1983, Parsons et al. 1983a, $1983 b)$. Photosynthetic rates are greater in younger leaf and the respiratory burden and shading of older plant material is avoided (Johnson and Parsons 1985, Parsons et al. 1988, Murphy 1990). In addition, production is enhanced through more rapid nutrient cycling (McNaughton 1979). These factors all result in more growth, an extended growing season and greater levels of water-use-efficiency in pastures that are grazed to maintain relatively low leaf area indices.

This study examines the leaf and tiller dynamics and harvest efficiency of Old World bluestem pasture under different levels of soil water and intensities of continuous stocking. In an adjacent study, Old World bluestem was maintained at 1,500, 1,900 and $2,400 \mathrm{~kg} \mathrm{ha}^{-1}$ with continuous variable stocking during 1992 and 1993 with normal rainfall (Teague et al. 1996). This concurrent study with irrigation was conducted to determine if a higher level of soil moisture would alter parameters influencing the proportion of leaf produced that is harvested (harvest efficiency). We hypothesize that under continuous stocking of Old World bluestem, increasing soil water level and grazing intensity will increase the leaf to stem and live to dead ratios, increase tiller density, and increase harvest efficiency. This basic information is needed to determine if grazing management to sustain efficient pasture and animal productivity needs to be different in dry compared to wet years or under irrigation.

Grazing was used in this study since estimates of the seasonal pattern of grass production, using intermittent cutting at regular intervals, differ substantially from those generated by studying the pasture under grazing (Barnes 1972, Coughenour et al. 1984, Blackburn and Kothmann 1989).

\section{Materials and Methods}

\section{Study Site}

The study was conducted on a 4-yearold, weed-free pasture of WW-Spar Old World bluestem (B. ischaemum (L.) Ken var ischaemum (WW-573). The study was located at a site $5 \mathrm{~km}$ east of Vernon $\left(34^{\circ}\right.$ $10^{\prime} \mathrm{N}, 100^{\circ} 16^{\prime} \mathrm{W}$ ) in north-central Texas. The climate is continental with an average 220 frost-free, growing days. Mean annual precipitation is $550 \mathrm{~mm}$, varying from 490 $\mathrm{mm}$ to $1,000 \mathrm{~mm}$, that is bimodally dis- tributed with peaks in May $(102 \mathrm{~mm})$ and September $(81 \mathrm{~mm})$. Evaporation averages $1,835 \mathrm{~mm}$ per annum $(607 \mathrm{~mm}$ diameter pan). Rainfall was recorded on-site and temperature was recorded $15 \mathrm{~km} \mathrm{NW}$ at the Vernon airport. Annual mean monthly temperature is $17.4^{\circ} \mathrm{C}$ ranging from $36.4^{\circ}$ $\mathrm{C}$ in July to $-2.3^{\circ} \mathrm{C}$ in January. Elevation is $390 \mathrm{~m}$ at the research site and slope is $1-3 \%$.

Soil was a Wichita clay loam (fine, mixed, thermic Typic Paleustalf) with an 'A' horizon permeability of 5-12 $\mathrm{mm} \mathrm{hr}^{-1}$ (USDA 1997). These soils are moderately alkaline $(\mathrm{pH}=7.8-8.5)$ and at the beginning of the experiment had no measurable nitrogen, moderate levels of phosphorus (12 ppm), high potassium (290 ppm), high calcium $(4,540 \mathrm{ppm})$, high magnesium $(600 \mathrm{ppm})$, no salinity, and very low sodium $(<10 \mathrm{ppm})$ and sulphur $(<1 \mathrm{ppm})$ based on dry soil weights.

\section{Pasture Management}

Two levels of soil moisture were maintained within each of 2 grazing intensity treatments outlined below, between May and August in both 1992 and 1993. These levels were: a control receiving incoming rainfall, and an irrigated treatment receiving rainfall plus $25 \mathrm{~mm}$ per week. Water was applied in 1 application per week using an overhead sprinkler irrigation system at a rate of approximately 12 $\mathrm{mm}$ /hour. Each irrigation treatment had 2 replicates allocated at random. Grazing intensity was not replicated. Within each grazing intensity area the irrigation plots were not separately fenced off. Each irrigated replicate plot was $4 \times 4 \mathrm{~m}$. Soil moisture was monitored volumetrically each week using a neutron probe to a depth of $1.2 \mathrm{~m}$ at intervals to the following depths $15,30,60,90$, and $120 \mathrm{~cm}$. The access tube was located in the center of each moisture level plot.

The 2 different grazing intensities were maintained using continuous, variable stocking. Each area was 0.25 ha in size. Stock numbers on the grazed pastures were adjusted weekly following pasture height measurement using a pasture discmeter (Bransby et al. 1977). The number of steers per pasture ranged from 3 to 8 . The target disc-meter heights were 35-40 $\mathrm{mm}$ (heavy) and 46-55 $\mathrm{mm}$ (light). The mean stocking rates for the treatments were $2.1 \mathrm{AUD} /$ ha (heavy), and 1.4 AUD/ha (light). Average standing crops were 1,548 , and $2,154 \mathrm{~kg} \mathrm{ha}^{-1}$ for the heavy and light pastures, respectively. A multiple regression model was developed, including disc-meter height and the percentage of live and dead leaf and culm to describe the relations between standing crop and disc-meter height. The $\mathrm{R}^{2}$ values were 0.93 and 0.92 for heavy and light pastures, respectively (Teague et al. 1996).

In 1992, the pastures were fertilized with $112 \mathrm{~kg} \mathrm{ha}^{-1}$ of nitrogen, as urea, in 2 equal dressings prior to expected rainfall in late April and late June. In 1993, only the April fertilizer application $\left(56 \mathrm{~kg} \mathrm{ha}^{-1}\right)$ was applied since the trial was terminated at the end of July. To remove residual standing crop from the previous season, all pastures were either burned (1992) or mowed (1993) in late winter. The pastures were stocked with steers on 4 May 1992 and 19 May 1993.

\section{Tiller Density and Leaf Area Index}

In 1992, dry weight, leaf and sheath area and number of tillers per unit ground area in the pastures were measured weekly on each treatment replicate by clipping 20 randomly located quadrats $\left(100 \mathrm{~cm}^{2}\right)$ at ground level. Lamina area was measured with an area meter (LiCor LI-3000, Lincoln, Nebr.). Samples were separated after drying into live or dead, lamina and stem (reproductive). To record possible winter mortality differences after these treatments, a total tiller count was made on 20 tufts in each treatment replicate in the fall of 1992. The tillers on these tufts were counted again after green-up in spring.

\section{Turnover and Fate of Leaves}

In 1993, leaf extension and death were measured in each of the treatment replicate plots. Tillers were marked with colored wire ties and measured weekly for a period of 6 weeks from 30 June 1993. A total of 40 tillers were marked per replicate. These were located 10 per line at random along 4 line transects radiating out from the center to each plot corner. Tillers with 5 to 6 leaves were chosen, 2 of which were usually fully expanded. At each randomly located point, the nearest tiller with 5 to 6 leaves was selected. Each lamina on each tiller was measured weekly to record lamina extension, lamina defoliation, lamina senescence, the emergence of a new leaf or the emergence of a daughter tiller. The same parameters were recorded for each daughter tiller that appeared on any mother tiller. 
Leaf senescence occurred on the older leaves and proceeded progressively from the tip towards the lamina base and finally the leaf sheath. Defoliation occurred on the younger, more elevated leaves and was noted by a clean removal of a part of the lamina. In most cases, these younger defoliated laminae continued to expand for a week or 2. Recent defoliations were easy to distinguish from week-old or older defoliations, owing to the development of a dry necrotic edge on the end of the defoliated laminae.

\section{Data Analysis}

Since irrigation but not grazing intensity was replicated, the significance of the main effects for irrigation and the irrigation by grazing intensity interaction were tested as a split plot with the soil moisture replicate as split plot error. Data were analyzed using ANOVA for soil moisture, standing crop, LAI and tiller density, and repeated measures analysis of variance for lamina extension, lamina defoliation and lamina senescence. For analysis of plant parts, standing crops and tiller survival, a General Linear Model (GLM) was used, with tiller density (tillers $\mathrm{cm}^{-2}$ ) as a covariant. Percentage values covered a wide range and did not require transformation. All analyses were carried out using the SAS statistical package (SAS 1988). Least significant difference tests (Steel and Torrie 1960) were used to separate means.

\section{Results and Discussion}

\section{Climate and Soil Moisture}

The temperatures in the 1992 growing period were slightly lower than the longterm means but 1993 temperatures were very close to the long-term means (Fig. 1). Evaporation in 1992 was similar to the long-term mean while that in 1993 was somewhat greater, particularly in July. Precipitation prior to growth in May 1992 and 1993 was above average. May was drier but June was wetter than average in 1992. In 1993, both May and June precipitation were slightly above average. July through September precipitation was average in both years.

Over the period that plant growth was measured in both 1992 and 1993, the nonirrigated control had significantly lower ( $P$ $<0.05)$ soil moisture than the irrigated treatment (Fig. 2). Differences in soil moisture in all treatments in the top $60 \mathrm{~cm}$ of soil, where $90 \%$ of old world bluestem

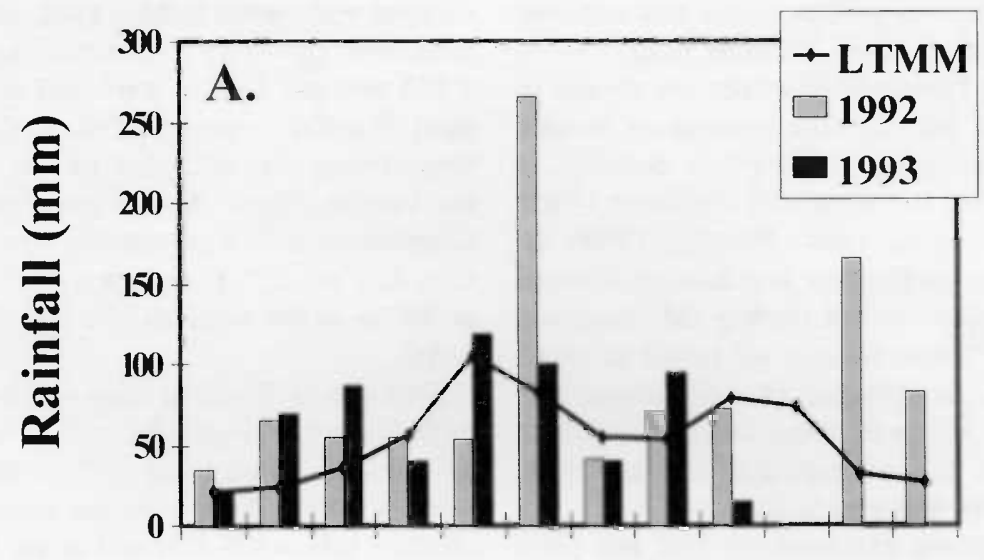

$\begin{array}{llllllllllll}\mathbf{J} & \mathbf{F} & \mathbf{M} & \mathbf{A} & \mathbf{M} & \mathbf{J} & \mathbf{J} & \mathbf{A} & \mathbf{S} & \mathbf{O} & \mathbf{N} & \mathbf{D}\end{array}$
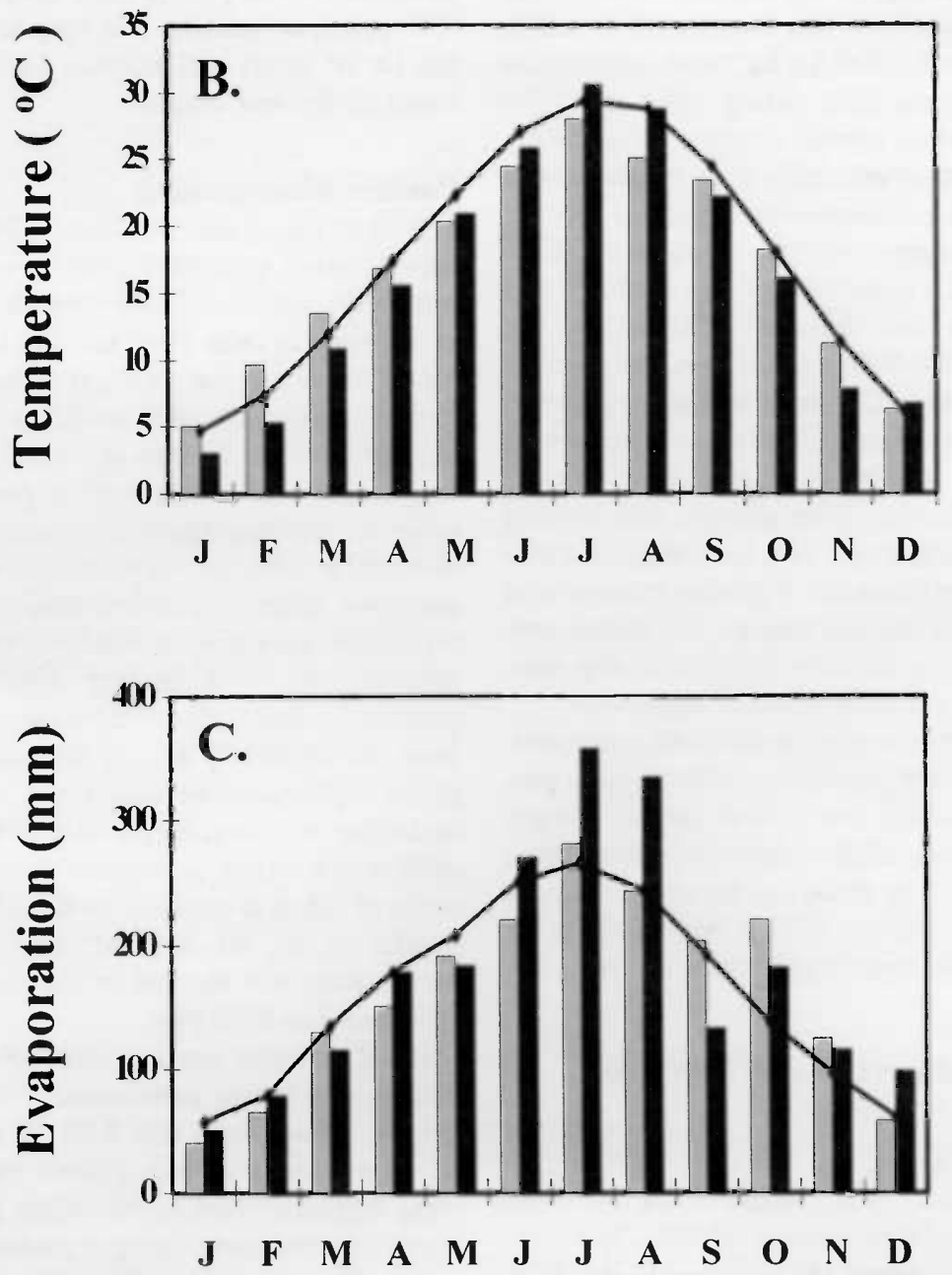

Fig. 1. Mean monthly weather data at the experimental site for 1992 and 1993 compared to long-term mean monthly (LTMM) data. (A) rainfall, (B) temperature, and (C) evaporation.

roots occur (Coyne and Bradford 1986), showed similar differences and levels of significance as illustrated for the full 120 $\mathrm{cm}$ profile presented in Fig. 2. In both years, soil moisture was lower in the light- ly grazed treatment than the heavily grazed treatment $(\mathrm{P}<0.10)$, probably due to the higher leaf area and live biomass in the lightly grazed treatment (Teague et al. 1996). 


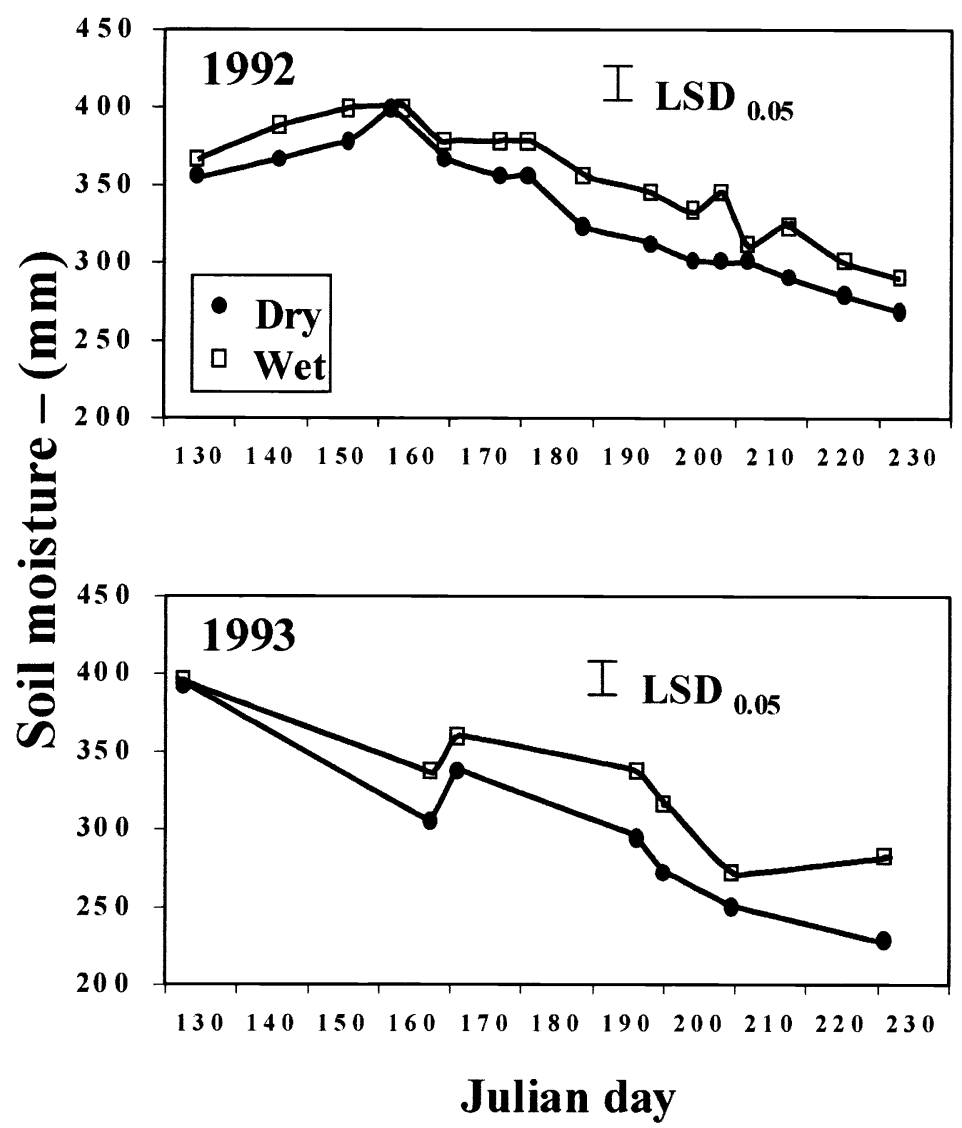

Fig. 2. Total soil moisture ( $\mathrm{mm})$ to $1.2 \mathrm{~m}$ depth for the irrigated treatment and non-irrigated control from mid May to the end of August for 1992 and 1993.
Leaf and Stem Proportions, Tiller Density and Leaf Area Index

Although the proportion of live and dead, leaf and stem was different at different dates during the experiment $(\mathrm{P}<0.05)$, there was no overall difference in proportions of these plant organ categories due to soil moisture per se $(\mathrm{P}>0.10)$ (Table 1) and no interaction between soil moisture and grazing intensity $(\mathrm{P}>0.10)$ regarding live and dead organ proportions. Tiller densities and leaf area index were not different between irrigation treatments $(\mathrm{P}>$ $0.10)$ (Table 2), and there were no interactions between soil moisture and grazing intensity regarding tiller density and leaf area index $(\mathrm{P}>0.10)$.
Winter tiller survival was significantly higher $(\mathrm{P}<0.05)$ in the irrigated treatments (Table 2) in a winter that was average for the area regarding temperature and soil moisture. However, there was no interaction between moisture level and grazing intensity $(P>0.10)$ regarding winter tiller survival.

\section{Harvest Efficiency}

Increasing soil moisture significantly increased overall plant height and total live leaf extension $(\mathrm{P}<0.10)$ (data not shown). Additional soil moisture also stimulated total leaf extension $(P<0.10)$ but it had no measurable effect on the pro-
Table 1. Contribution of different plant organs to standing crop of Old World bluestem pastures at 2 levels of soil moisture in 1992.

\begin{tabular}{lccccc}
\hline \hline \multicolumn{5}{c}{ Standing crop } \\
\hline $\begin{array}{l}\text { Moisture } \\
\text { Level }\end{array}$ & Live leaf & Dead leaf & Live stem & Dead stem & Total \\
\hline & & & & & \\
Wet $^{1}$ & $94.0^{\mathrm{a}}$ & $25.1^{\mathrm{a}}$ & $48.9^{\mathrm{a}}$ & $7.8^{\mathrm{a}}$ & $175.8^{\mathrm{a}}$ \\
Dry $^{\mathrm{a}}$ & $94.0^{\mathrm{a}}$ & $24.2^{\mathrm{a}}$ & $48.7^{\mathrm{a}}$ & $8.7^{\mathrm{a}}$ & $175.6^{\mathrm{a}}$ \\
Pooled s.e. & 3.5 & 1.9 & 3.6 & 0.6 & 7.5 \\
\hline
\end{tabular}

${ }^{1}$ Means within columns with same subscripts are not significantly different $(P>0.05)$.
Table 2. Density of primary tillers $\left(\mathrm{cm}^{-2}\right)$ and leaf area index during the 1992 growing season at 2 levels of soil moisture and the number of tillers $\left(\mathrm{cm}^{-2}\right)$ surviving winter in Old World bluestem pastures.

\begin{tabular}{|c|c|c|c|}
\hline $\begin{array}{l}\text { Moisture } \\
\text { level }\end{array}$ & Wet & Dry & $\begin{array}{c}\text { Pooled } \\
\text { s.e. }\end{array}$ \\
\hline Tiller density ${ }^{1}$ & $3.81^{\mathrm{a}}$ & $3.82^{\mathrm{a}}$ & 0.56 \\
\hline Leaf area index & $1.22^{\mathrm{a}}$ & $1.14^{\mathrm{a}}$ & 0.06 \\
\hline Tiller survival & $2.03^{\mathrm{a}}$ & $1.70^{\mathrm{b}}$ & 0.065 \\
\hline
\end{tabular}

'Means within rows with different subscripts are significantly different $(\mathrm{P}<0.05)$

portion of dead leaf $(P>0.10)$ even though the number of dead leaves per tiller was higher with increasing soil moisture $(\mathrm{P}<0.10)$ (Table 3). However, a greater percentage of total leaf (length) died in the low soil moisture treatment $(\mathrm{P}<0.10)$ so decreasing soil moisture had the effect of increasing the proportion of leaf that died and was not grazed, resulting in a lower harvesting efficiency. The amount of leaf (length) that was grazed increased with increasing soil moisture $(\mathrm{P}<0.10)$, but the percentage of total leaf grazed was similar at different soil moisture levels $(\mathrm{P}>0.10)$. Increased soil moisture had no effect on the number of new leaves per tiller $(\mathrm{P}>$ 0.10 ) (Table 3).

There were interactions between soil moisture and grazing treatments regarding length of live leaf and dead leaf produced (data not shown). Increasing soil moisture interacted with increasing grazing pressure to increase live leaf production $(\mathrm{P}<0.01)$. High soil moisture and heavier grazing also interacted to reduce the proportion of dead leaf $(\mathrm{P}<0.10)$ and increase production of new tillers $(\mathrm{P}<0.05)$.

The low level of response by Old World bluestem to the irrigation treatments is surprising since there was a significantly lower level of soil moisture in the non-irrigated control compared to the irrigated treatment. It is possible that the close to average precipitation during this study, resulted in insufficient water stress in the lower moisture treatment to cause significant differences, since a response to different levels of soil moisture is probably contingent upon differences in moisture stress exceeding a certain level (Busso and Richards 1995). However, grass response to irrigation alone may be smaller than other treatments and the greatest increases in plant growth occur when irrigation is combined with other treatments (Risser et al 1981). 
Table 3. The effect of different levels of irrigation on plant stature and the turnover and fate of leaves on Old World bluestem pastures.

\begin{tabular}{lcc}
\hline \hline Moisture level & Dry & Wet \\
\hline Total leaf extension $(\mathrm{mm})^{1}$ & $149^{\mathrm{a}}$ & $259^{\mathrm{b}}$ \\
Total leaf death $(\mathrm{mm})$ & $261^{\mathrm{a}}$ & $253^{\mathrm{a}}$ \\
Total leaf grazed $(\mathrm{mm})$ & $159^{\mathrm{a}}$ & $237^{\mathrm{a}}$ \\
Dead leaf as \% of total leaf & $66^{\mathrm{a}}$ & $45^{\mathrm{b}}$ \\
Grazed leaf as \% of total & $40^{\mathrm{a}}$ & $47^{\mathrm{a}}$ \\
Number of new leaves per tiller & $2.7^{\mathrm{a}}$ & $3.6^{\mathrm{a}}$ \\
Number of dead leaves per tiller & $4.4^{\mathrm{a}}$ & $5.3^{\mathrm{b}}$ \\
Number of leaves grazed per tiller & $1.4^{\mathrm{a}}$ & $2.4^{\mathrm{a}}$ \\
\hline
\end{tabular}

${ }^{1}$ Means within rows with different subscripts are significantly different $(\mathrm{P}<010)$.

In a species such as Old World bluestem, which is adapted to a semi-arid environment (Sims and Dewald 1982), an inherent ability to maintain a low density of tillers may increase survival and fitness. A feature of Old World bluestem in the field is that there are distinctive tufts surrounded by bare ground, resulting in the low tiller densities and LAIs reported here. There may be adaptive significance to having lower tiller densities and less or slower growth to survive and compete successfully under more stressful and variable conditions. Lower densities of perennial grasses are believed to be more competitive with invading grass species in semi-arid environments (Buman et al. 1988, Pyke and Archer 1991).

Species differ markedly in how they respond above and below ground to different levels of herbivory (Briske 1993). Those that have demonstrated the ability to withstand severe herbivory and prosper, generally require a high level of resources, i.e. water and nutrients, to do so (Maschinski and Whitham 1989, Holland et al. 1992, Briske 1991). Nitrogen fertilizer levels in this study were moderately low (Taliaferro et al. 1975, Teague et al. 1996) and nitrogen was, therefore, probably moderately limiting. Coyne and Bradford (1986, 1987) report that with Old World bluestem, greater levels of nitrogen increase photosynthetic efficiency per unit leaf area and maintain a higher and more constant growth rate. Nitrogen deficiency also reduced growth and competitive ability in a number of other species by slowing leaf appearance rate and limiting tillering capacity (Wilson and Brown 1983, Thomas et al. 1990, Tallowin and Brookman 1996). It is possible that low nitrogen may have resulted in low tiller densities and the lack of response to the irrigation treatment in this study.

\section{Conclusions}

Maximizing the amount of secondary productivity per hectare involves balancing the efficiency of capturing incoming solar radiation and forage production with forage quality and harvesting efficiency. Leaf area index and tiller density influence capture of solar radiation and forage production per hectare, while density of live leaf and the ratios of live to dead, and leaf and stem, influence diet quality and harvesting efficiency. In the companion, rain fed study where Old World bluestem was maintained at 1,500, 1,900, and $2,400 \mathrm{~kg}$ $\mathrm{ha}^{-1}$, the shorter pastures had a greater proportion of leaf, live stem, percentage of crude protein, and weight gain per hectare (Teague et al. 1996). The results of this study indicate that increasing soil moisture level and grazing intensity interacted to increase the proportion of leaf produced that was harvested (harvest efficiency), reduce the proportion of dead leaf, and increase production of new tillers and winter tiller survival. However, increasing soil water level did not increase tiller density during the summer growing period. In addition, increasing soil water level did not increase the leaf to stem and live to dead ratios as hypothesized. This study indicates that if continuously grazed Old World bluestem is maintained at a standing crop of $1,500 \mathrm{~kg} \mathrm{ha}^{-1}$, harvesting efficiency is higher in wet years or under irrigation than if standing crop is higher.

\section{Literature Cited}

Barnes, D.L. 1972. Defoliation effects on perennial ryegrass - continuing confusion. Proc. of the Grassl. Soc. of Southern Africa 7:138-145.

Blackburn, H.D. and M.M. Kothmann. 1989. A forage dynamics model for use in range or pasture environments. Grass and Forage Sci. 44: 283-294.
Bransby, D.I., A.G. Matches, and G.F. Krause. 1977. Disc meter for rapid estimation of herbage yield in grazing trials. Agron. J. 69:393-396.

Briske, D.D. 1991. Developmental morphology and physiology of grasses, p. 85-108. In: R.K. Heitschmidt and J.W. Stuth, (eds.), Grazing management: an ecological perspective. Timber Press, Portland, Ore.

Briske, D.D. 1993. Grazing optimization: a plea for a balanced perspective. Ecol. Appl. 3:24-26.

Buman, R.D. S.B. Monsen, and R.H. Abernethy. 1988. Seedling competition between mountain rye, 'Hycrest' crested wheatgrass and downy brome. J. Range Manage. 41:30-34.

Busso, C.A. and J.H. Richards. 1995. Drought and clipping effects on tiller demography and growth of two tussock grasses in Utah. J. Arid Environ. 29:239-251.

Coughenour, N.B., S.J. McNaughton, and L.L. Wallace. 1984. Modelling primary production of perennial graminoids. Ecol. Model. 23:101-134.

Coyne, P.I. and J.A. Bradford. 1985. Some growth characteristics of four Old World bluestems. J. Range Manage. 38:27-32.

Coyne, P.I. and J.A. Bradford. 1986. Biomass partitioning in 'Caucasian' and 'WW-Spar' Old World bluestems. J. Range Manage. 39:303-310.

Coyne, P.I. and J.A. Bradford. 1987. Nitrogen and carbohydrate partitioning in 'Caucasian' and 'WW-Spar' Old World bluestems. J. Range Manage. 40:353-360.

Dabo, S.M., C.M. Taliaferro, S.W. Coleman, F.P. Horn, and P.L. Claypool. 1987. Yield and digestibility of Old World bluestem grasses as affected by cultivar, plant part and maturity. J. Range Manage. 40:10-15.

Eck, H.V. and P.L. Sims 1984. Grass species adaptability in the Southern High Plains36-year assessment. J. Range Manage. 37:211-217.

Forbes, T.D.A. and S.W. Coleman. 1986. Herbage intake and ingestive behavior of grazing cattle as influenced by variation in sward characteristics, p. 141-152. In: F.P Horn, (ed.), Grazinglands research at the plant animal interface. Winrock Int., Morrilton, Ark.

Grant, S.A., G.T. Barthram, L. Torvell, J. King, and K. Smith. 1983. Sward management, lamina turnover and tiller population density in continuously stocked Lolium perenne dominated swards. Grass and Forage Sci. 38:333-344.

Holland, E.A.W., W.J. Parton, J.K. Detling, and D.L. Coppock. 1992. Physiological responses of plant populations to herbivory and their consequences for ecosystem nutrient flow. American Naturalist 142:685-706.

Johnson, I.R. and A.J. Parsons. 1985. Use of a model to analyze the effects of continuous grazing managements on seasonal patterns of grass production. Grass and Forage Sci. 40:449-458. 
Maschinski, J. and T.G. Whitham. 1989. The continuum of plant responses to herbivory: the influence of plant association, nutrient availability, and timing. Amer. Natur. 134:1-19.

McNaughton, S.J. 1979. Grazing as an optimization process: grass-ungulate relationships in the Serengeti. Ameri. Natur. 113:691-703.

Murphy, B. 1990. Pasture Management, $p$ 231-262. In: C.A. Francis, C.B. Butler and L.D. King, (eds.), Sustainable Agriculture in Temperate Zones. Wiley-Interscience, New York.

Parsons, A.J., I.R. Johnson, and A. Harvey. 1988. Use of a model to optimize the interaction between frequency and severity of intermittent defoliation and to provide a fundamental comparison of the continuous and intermittent defoliation of grass. Grass and Forage Sci. 43:49-59.

Parsons, A.J., E.L. Leafe, B. Collett, and W. Stiles 1983a. The physiology of grass growth under grazing. I. Characteristics of leaf and canopy photosynthesis of continuously grazed swards. J. Appl. Ecol. 20:117-126.
Parsons, A.J., E.L. Leafe, B. Collett, P.D. Penning, and J. Lewis. 1983b. The physiology of grass growth under grazing. II. Photosynthesis, crop growth and animal intake of continuously grazed swards. J. Appl. Ecol. 20:127-139.

Pyke D.A. and S. Archer. 1991. Plant-plant interactions affecting plant establishment and persistence on revegetated rangeland. J. Range Manage. 44:550-557.

Risser, P.G., E.C. Birney, H.D. Blocker, S.W. May, W.J. Parton and J.A. Wiens. 1981. Ecosystem responses to stress, p. 332436. In: P.G. Risser, E.C. Birney, H.D Blocker, S.W. May, W.J. Parton and J.A. Wiens, (eds). The True Prairie Ecosystem, US/IBP Synthesis Series 16.

Sims, P.L. and C.L. Dewald. 1982. Old World bluestems and their forage potential for the Southern Great Plains. USDA Agr . Res. Serv., Agr. Revi. and Manuals, ARM-S-28.

SAS Institute. 1988. SAS/STAT User's Guide. SAS Institute Inc., Cary, N.C

Steel, R.G.D. and Torrie, J.H. 1960. Principles and procedures of statistics, McGraw-Hill, New York.
Taliaferro, C.M., F.P. Horn, B.B. Tucker, R. Totusek, and R.D. Morrison. 1975. Performance of three warm-season perennial grasses and a native range mixture as influenced by $\mathrm{N}$ and $\mathrm{P}$ fertilization. Agron. J 67:289-292.

Tallowin, J.R.B. and S.K.E. Brookman. 1996. The impact of differences in nitrogen content, nitrogen utilization and loss from laminae on competition between four grasses in an old pasture. J. Agr. Sci. 126:25-35.

Teague, W.R., S.L. Dowhower, W.E Pinchak, D.R. Tolleson and L.J. Hunt. 1996. Increasing utilization efficiency of continuously grazed Old World bluestem pasture. J. Range Manage. 49:535-540.

Thomas, R.J., K.A.B Logan, A.D. Ironside, and G.R. Bolton. 1990. The effects of grazing with and without excretal returns on the accumulation of nitrogen by ryegrass in a continuously grazed upland sward. Grass and Forage Sci. 45:65-75

USDA. 1997. USDA-NRCS Official Soil Series Description 6/97. Available online at http://www.statlab.iastate.edu/cgibin/osd/osdname.cgi.

Wilson, J.R. and R.H. Brown. 1983. Nitrogen response of Panicum species differing in $\mathrm{CO}_{2}$ fixation pathways. I. Growth analysis and carbohydrate accumulation. Crop Sci. 23:1148-1153.

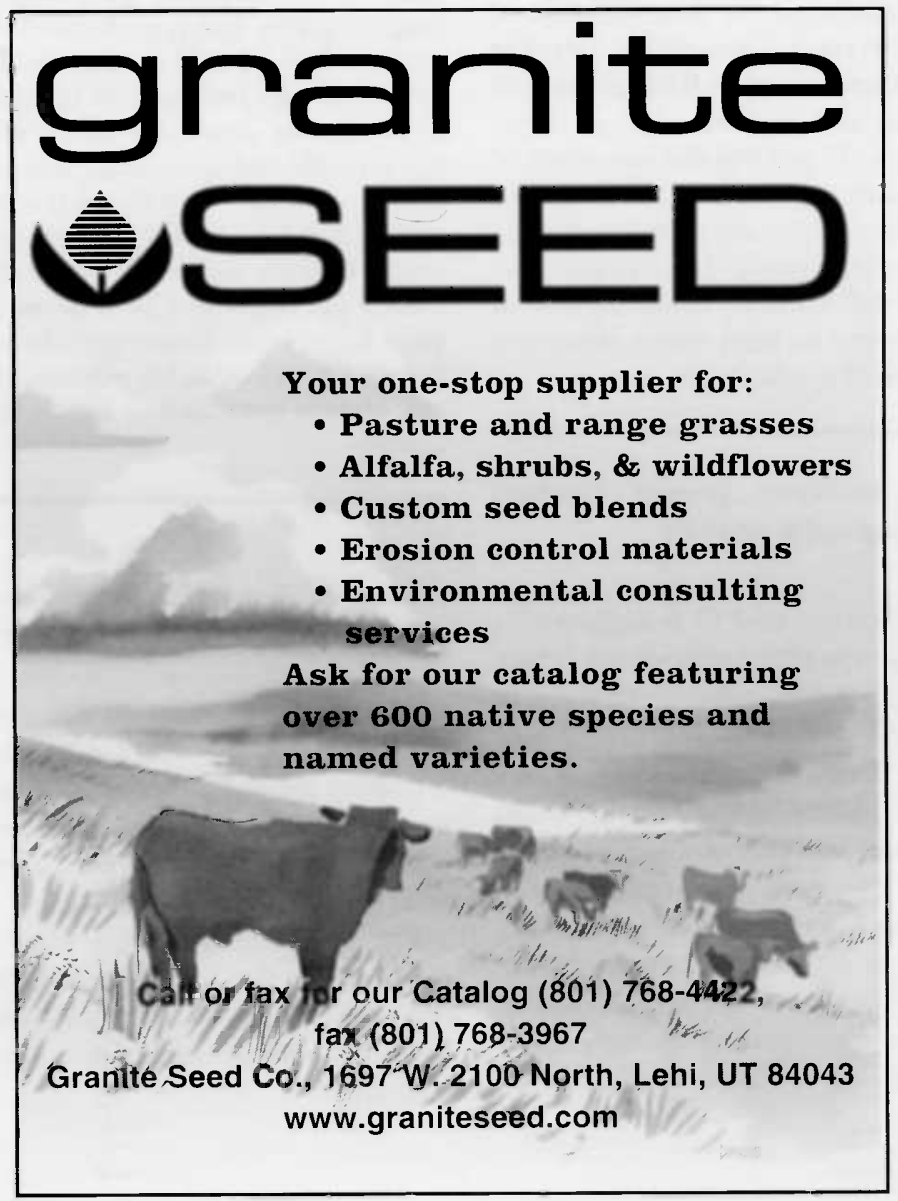

